\title{
Nigeria
}

\section{Awards of monetary judgment in a foreign currency by Nigerian courts}

\author{
by Mutiu Ganiyu
}

When the case of Melwani ${ }_{V}$ Chanrai Corporation reported in 19956 NWLR, Part 402 at p. 438, got to the Court of Appeal (Lagos Division) to decide the issue of whether a Nigerian court can award monetary judgment in a foreign currency, the expectation was that the court was going to give a positive answer to the question and the case would have joined a long line of other cases like Metronex Nigeria Ltd $v$ Griffin \& George Ltd (1991) 1 NWLR pt. 169 at p. 655, Olaogun Enterprises Ltd v SJ \& M 1992, 4 NWLR pt. 235 at p. 361, UBA v Ibhafidon 1994, 1 NWLR pt. 318 , at p. 90, where it had already been held that Nigerian courts can award monetary judgment in a foreign currency.

However, it was held that a Nigerian court can only give judgment in the Naira (NGN), which is the Nigerian currency, and that it cannot give judgment in a foreign currency. This decision, no doubt, is discomfiting both to the Nigerian commercial community and foreigners transacting business in Nigeria or with Nigerians.

\section{THE FACTS}

In the Melwani case the plaintiff, as an alternative relief before the lower court (i.e. the High Court), asked for the refund of the sum of US\$2,820,115 which he claimed to have paid to the defendant as consideration for an alleged agreement for the transfer of some shares by the defendant to the plaintiff in $\mathrm{X}$ company, which agreement the defendant was alleged to have breached.

The lower court found for him, and he was awarded the sum of US\$2,820,115 after trial. It was upon the appeal of the defendant to the Court of Appeal that the decision was reversed holding, among other reasons, that a Nigerian court cannot give judgment in a foreign currency.

At p. 461 of the reports, the court was of the opinion that its earlier unreported decision in the Ibadan Division of the court in the case of $U B A_{v}$ Koya CA/I/106/87, decided on 1 September 1988, where it was held that Nigerian courts cannot give judgment in a foreign currency, represents the law on the issue and that the case of Olaogun Enterprises $v$ SJ \& $M$ and, by implication, other cases suggesting otherwise, were decided per incuriam. The incuria being that the case of UBA $v$ Koya was not cited in these cases.

In advancing this position, Honourable Justice Uwaifo reasoned as follows, at p. 467:

'I shudder to think of our Courts putting Nigeria in a situation where judgments in a foreign currency are allowed a free reign to drain our foreign reserve.'

Furthermore, his Lordship was of the opinion that a judgment given in a foreign currency in any case would offend the provisions of Exchange Control Act 1962, which provides that one of the requirements to be satisfied before payment of money outside Nigeria can be made is that of the Minister's approval and that in the absence of that, a judgment given in a foreign currency is, more or less, going to be unenforceable.

Not too long after the decision in the Melwani's case, the same division of the Court of Appeal (i.e. the Lagos Division) was confronted with the same issue of whether Nigerian courts are endowed with the power of giving judgments in foreign currency. The Honourable Justice Uwaifo who read the leading judgment in the Melwani's case read the leading judgment in the current case and relying on the Melwani's case reiterated his earlier opinion that Nigerian courts cannot give judgment in foreign currency. See the case of Salzgitter Stahl GmBH v Tunji Dosunmu Industries Ltd (unreported) CA/L/169/90 delivered on 8 February 1996.

However, one of the Justices of the court that sat on the panel, Justice $\mathrm{O}$ Ayoola, while not formally dissenting from the opinion of Justice Uwaifo, sounded a note of caution in the following words:

'Before I part with the matter, it is expedient to sound a note of warning. It is my view that should we embrace a principle that will be manifestly unjust to the country's trading partners, much havoc would be done to the country's international trade. It is not right to make a foreign creditor take in effect, less than he is entitled to, merely because the Naira has fallen in value since the obligation was incurred. For instance, a foreign creditor who supplied goods worth US\$100,000 when the rate of exchange was say 5 Naira to 1 US Dollar, would be expected now to take NGN 500,000 in settlement notwithstanding that at the current rate of exchange that would convert to less than 6,000 US Dollars. Suppose he had borrowed 75,000 US Dollars to finance the supply of goods, he would end up with a loss of little less than 70,000 US Dollars all through no fault of his! What appears to me just, is that if the money of account is expressed in foreign currency, the Nigerian buyer must provide enough Naira to pay the foreign supplier what he is entitled to in the agreed amount of foreign currency. If the Naira depreciates in terms of the foreign currency, the foreign creditor still recovers the amount of foreign currency agreed, notwithstanding that the Nigeria debtor would need to look for more Naira to perform his obligations ... I hold that the High Court could give judgment expressed in foreign currency.'

\section{SOURCE OF DISCOMFITURE}

[In Melwani] it was held that a Nigerian court can only give judgement in the Naira ... no doubt ... discomfiting both to the Nigerian commercial community and foreigners transacting business in Nigeria or with Nigerians. 


\section{CRITICISMS}

The issue however, reared its head in two other cases before different divisions of the court (Benin and Kaduna) and it was found, in the two cases, that the Nigerian courts could give judgment in a foreign currency. The cases are Prospect Textile Mills (Nigeria) Ltd v Imperial Chemical Industries plc 1996 NWLR, pt. 457, at p. 668 and Salzgitter Stahl GmbH v Aridi Industries Nigeria Ltd 1996, 7 NWLR at p. 192. Unfortunately, the case of Melwani was not cited in either of these two cases.

The conflict of opinions no doubt, has been brought about as a result of the fact that the Court of Appeal sits concurrently in eight different judicial divisions, presided over by different judges who may not be aware of an earlier decision of their colleagues on an issue before them, especially if such earlier decisions were not reported. In this type of situation, a pronouncement of the Supreme Court on the issue settles the law.

\section{CONCLUSION}

With the obiter dictum of the Nigerian Supreme Court that Nigerian courts can award judgment in a foreign currency in the case of Broadline Enterprises Ltd v Monterey Maritime Corp (1995) 9 NWLR at p. 1 and Koya $v$ UBA ([1991], 1 NWLR pt. 481, at p. 25(Supreme Court)) and the decision of the same court in Alao $v$ ACB 1997, 3 NWLR pt. 542, at p. 339, where it was held that the Exchange Control Act 1962, relied on in Melwani's case, has been repealed, one can positively assert that when Melwani's case, which is now pending before the Supreme Court falls due for a decision, that court will uphold the view that a Nigerian court can award judgment in a foreign currency.

\section{Mutiu Ganiyu}

Aluko \& Oyebode, Barristers, Solicitor \& Trademarks Agents 35, Moloney Street, Lagos

\section{Annotated Guide to the Insolvency Legislation}

\section{F IFTH EDITION}

This "bible" of the insolvency profession...

- Reproduces the full texts of the Insolvency Act 1986, the Company Directors Disqualification Act 1986 and the Insolvency Rules 1986, as amended.

- Incorporates all recent statutory amendments, including those from the Pensions Act 1995 and the Trusts of Land and Appointment of Trustees Act 1996.

- Offers detailed annotation on the provisions explaining their meaning, effects and implications in the light of the now significant body of case law.

- Includes helpful cross-references to relevant rules and regulations.

- Includes history notes, setting out the former wording of those repealed or amended provisions that are still of current importance to practitioners.

- Provides a useful list of terms defined in the legislation.

Annotations written by Len Sealy, S J Berwin Professor Emeritus of Corporate Law at the University of Cambridge and David Milman, Herbert Smith Professor of Corporate Law at the University of Manchester.

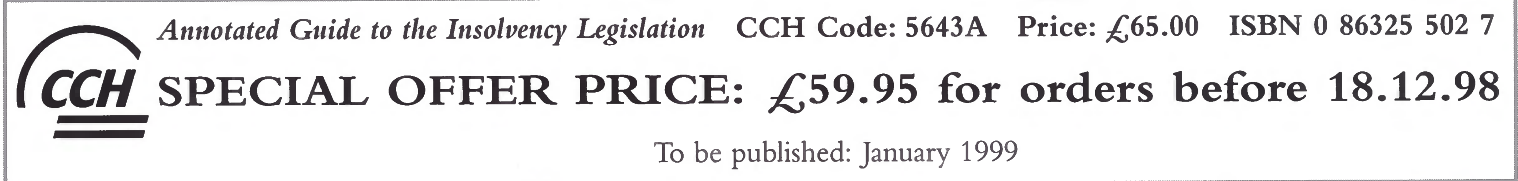

Call Customer Services on +44 (0)1869 872336 quoting reference ZGVS for details 